\title{
National CSR and institutional conditions: an exploratory study
}

Article

Accepted Version

Creative Commons: Attribution-Noncommercial-No Derivative Works 4.0

Halkos, G. and Skouloudis, A. (2016) National CSR and institutional conditions: an exploratory study. Journal of Cleaner Production, 139. pp. 1150-1156. ISSN 0959-6526 doi: https://doi.org/10.1016/j.jclepro.2016.07.047 Available at https://centaur.reading.ac.uk/70222/

It is advisable to refer to the publisher's version if you intend to cite from the work. See Guidance on citing.

Published version at: http://dx.doi.org/10.1016/j.jclepro.2016.07.047

To link to this article DOI: http://dx.doi.org/10.1016/j.jclepro.2016.07.047

Publisher: Elsevier

All outputs in CentAUR are protected by Intellectual Property Rights law, including copyright law. Copyright and IPR is retained by the creators or other copyright holders. Terms and conditions for use of this material are defined in the End User Agreement.

\section{www.reading.ac.uk/centaur}

\section{CentAUR}

Central Archive at the University of Reading

Reading's research outputs online 
National CSR and institutional conditions: An exploratory study

\author{
George Halkos ${ }^{1}$ and Antonis Skouloudis ${ }^{2^{*}}$ \\ ${ }^{1}$ Laboratory of Operations Research, University of Thessaly, \\ Volos, 38 333, Greece \\ ${ }^{2}$ Henley Business School, University of Reading, Greenlands, \\ Henley-on-Thames, RG9 3AU, UK \\ *corresponding author
}

\begin{abstract}
Corporate social responsibility (CSR) footprints in terms of relevant policies, plans and programs are evident at a global scale, but the level of national uptake and penetration differs, as countries differ considerably in terms of institutional efficiency. With this in mind, the purpose of this study is to investigate the relationship between CSR penetration and institutional conditions that shape and define the macroeconomic environment and development dynamics of countries. Building on Campbell's seminal propositions on institutional parameters that facilitate effective CSR management, the study's results lend partial support to his conceptual framework as it was operationalized in our assessment. Civic engagement, regulatory effectiveness and competitive conditions appear to be very significant factors influencing CSR penetration with macroeconomic conditions and industrial self-regulation to play a less significant role on national CSR penetration. These findings provide fertile ground to theorists and researchers for a deeper investigation of the impact of institutional arrangements that define the national specificity of CSR and act as moderators of responsible business behavior.
\end{abstract}

Keywords: Corporate social responsibility (CSR); national institutions; national index; cross-country analysis. 


\section{Introduction}

Since the 1990s, corporate social responsibility (CSR), as an emerging area of study of organizational management has expanded and the umbrella-term of responsible business conduct has gained increasing attention at a global scale under the scope of mitigation, stewardship and sustainability concerns (Wood, 2010; Lozano 2012). Nevertheless, this continuously expanding sub-field of business literature pertains mostly to studies focusing at the micro-level and meso-level within certain national environments while there is limited research at the macro-level (i.e. national and cross-country assessments). Blowfield (2005) stresses that the discourse fostered by contemporary CSR necessitates expanded lenses of analysis in which alternative frameworks for exploring the structural dimensions of CSR would be crucial. In a similar vein, Ringov and Zollo (2007) point out that a solid empirical base to link national specificity with CSR is absent with most of the debate to be fueled by either conceptual arguments or anecdotal evidence. In this context, critical questions posed to policy-makers and scholars respectively are: why firms in some countries are more socially responsible than firms in other countries? What are the factors that affect CSR across countries? Which institutional parameters facilitate strong CSR penetration in a national economy and why the business sector in certain countries and regions exhibits comparatively weaker CSR penetration?

The paper attempts to respond to such pressing questions and contribute to the scant literature of institutionally-bound CSR assessment with the guiding research question to be the investigation of the impact of national institutions on the proliferation of socially responsible behavior. To this end, it builds on the seminal work of Campbell (2007) published in the Academy of Management who sets forth a series of assertions grounded on institutional theory on why firms engage in socially responsible behaviors. Such normative arguments, referring to macroeconomic stability, competition, industrial self-regulation, regulatory quality as well as civic activism, are empirically examined and operationalized at the national level in the present study. Campbell's framework stresses that the voluntary and proactive practices that the CSR construct posits, part of the wider spectrum of activities pertaining to the interaction between business and society, are fundamentally determined by the institutional terrain within which a firm operates. Campbell's work paved the way for a more comprehensive investigation of comparative CSR trends and developments under the nexus of institutional structures and the efficiency of national institutional conditions. His framework marked the contested and contingent nature of the CSR notion by suggesting that the responsibility of business to society is defined by societal demands and expectations as these are embodied in a country's formal and informal institutions. Other theorists have drawn on his work to stress the value of institutional lenses in understanding broader socioeconomic, historical and political determinants of whether and in what courses of action business entities may take on social responsibilities (e.g. Brammer et al. 2012). For instance, Matten and Moon (2008) and Jackson and Apostolakou (2010) assert that in countries pertaining to the Anglo-Saxon model companies tend to engage more explicitly in voluntary 
policies, plans and practices of social responsibility whereas in countries with coordinated market economies aspects of organizational responsibility are embedded and shaped by legal regulation and other formal institutions. In a similar vein, Witt and Redding (2012) focus on senior executives from diverse institutional environments and provide supporting evidence that highlight country variations in CSR conceptualization and the related salience attached to various organizational stakeholder groups. Nevertheless, despite Campbell's paper has received numerous citations ${ }^{1}$ and scholars tend to refer to his propositions when developing normative arguments on the political economy of CSR, none has attempted to empirically examine his propositions as testable hypotheses.

Motivated by the work of scholars such as the previous and by drawing upon Campbell's framework as the basis of the assessment presented in this paper, we seek to contribute to the empirical literature on institutional determinants of CSR. This is the first study to offer finding on the role of national institutions on CSR penetration which draws on the largest (to date) sample of countries around the world utilizing findings on the level of country-level CSR penetration by Skouloudis (2014) and Skouloudis et al. (2016). Taking into consideration data availability for various institutional conditions as well as the limitations of cross-country CSR assessments, the study paves the ground for further empirical investigation of the institutional conditions that define CSR proliferation among countries.

The rest of the paper is structured as follows: Section 2 outlines prior literature along with Campbell's theoretical model and propositions. Next, the data and methods are described followed by the presentation of results. Finally, the discussion of our findings and concluding remarks on opportunities for future research wrap up the paper.

\section{Background}

The institutional conditions of a country have been pinpointed for their enormous influence over organizational decisions or actions. In this regard, the institutional environment has been characterized as the 'rules of the game' (Thelen, 1999), defining business actions and regarded as essential antecedent of the development potential of nations by enabling stability and facilitating market efficiency. Findings by Globerman and Shapiro (2002) as well as Harms and Ursprung (2002) indicate a positive relationship between foreign direct investment inflows (FDIs) and the institutional conditions of countries while a negative relationship of FDIs with the relative level of national corruption has also been documented (Habib and Zurawicki, 2002). Nevertheless, as Barley (2007) criticizes, there is an evident 'lag' in the management literature in attending a broader understanding of the interaction between for-profit organizations and their multifaceted institutional environment.

The long debate on corporate responsibility has placed comparatively more emphasis on the relation between social and financial performance (Margolis et al.,

\footnotetext{
${ }^{1}$ According to Google Scholar his paper has been cited by almost 2000 authors.
} 
2007) in an attempt to signify CSR as a missing link in improving the financial bottom line and competitiveness (Porter and Kramer, 2006; Vilanova et al., 2009). Despite viewed as a global issue endorsed over the years by international organizations and through transnational best-practice schemes, CSR penetration has exhibited increased variation across regions and countries (Welford 2003; 2005). Such variation pertains to the level as well as the focus of corporate involvement (Marquis et al., 2007) something which is attributed to discrepancies in the institutional efficiency among countries. Yet, CSR scholars have been somewhat slow to investigate the effects of institutional conditions on responsible business conduct (Aguilera et al., 2007; Jackson and Apostolakou, 2010). It is only during the mid2000s when the conceptual approaches in exploring the CSR construct have expanded to include the institutional lens to better understand nonfinancial aspects of corporate responsibility (e.g. Aguilera et al., 2007).

A growing body of literature indicates that corporate responsibility is dependent on and embedded in a nexus of institutions that characterize the national identity of each country (Khanna et al., 2006). Placing CSR within the wider terrain of institutional mechanisms allowed the initiation of a more cross-disciplinary inquiry of responsible business conduct through different modes pertaining to political economy, political science, corporate law, sociology of organizations, cultural traits, religious norms and/or regional traditions as well as the relational pressures that stem from such institutional aspects. For instance, research evidence by Baskin (2006) and Jamali et al. (2009) echoes supporting arguments on the institutional interplay between state policies, private sector discretionary activities and civil society's activism in shaping the CSR penetration among national contexts. Scholars are beginning to identify the critical importance of institutions in explaining CSR-specific aspects (Jamali and Neville, 2011), such as human resources management (Edelman and Suchman, 1997), environmental performance (Bansal and Roth, 2000), nonfinancial accountability (Chen and Bouvain, 2009) or community relations (Guthrie and McQuarrie, 2004).

Still, cross-country comparisons between CSR and national institutional settings remain relatively sparse (e.g. Jackson and Apostolakou, 2010), compared to other fields business research (Gedajlovic and Shapiro, 1998; Williams and Aguilera, 2008). In addressing this gap in the literature, this study draws on aspects of Campbell's framework of institutional conditions and empirically tests them among a large pool of countries assessed in terms of CSR penetration.

\subsection{Institutional conditions vis-à-vis CSR: Outlining Campbell's framework}

In his seminal paper, Campbell (2007) builds his argumentation around a central question: taking into account the overarching profit-maximization principle and opportunistic tendencies of business entities, what conditions facilitate the socially responsible conduct of companies or why would a firm operate in socially responsible ways? According to his viewpoint, firms that act in a socially responsible manner are either not knowingly do anything that could harm their stakeholders or, when they do cause such harm, rectify it whenever it is brought to their attention. 
Acknowledging that responsible corporate behavior varies across countries, analysis to assert that that the way companies manage stakeholder demands and expectations is dependent on the institutions within which they operate. In this context, he formulates a set of propositions framing specific institutional conditions that affect firms' propensity to act in socially responsible ways.

First, Campbell denotes that companies with low profitability possess comparatively fewer slack resources to employ towards CSR practices. Even so, such is the case for firms experiencing financial losses and exhibit weak financial performance. In this context, focusing at the macro-level, he emphasizes the vital importance of the macroeconomic climate for CSR endorsement; macroeconomic downturn and an 'unhealthy' or unstable economic environment can have a direct effect on business profitability which in turn influences socially responsible behavior.

Second, he conceptualizes a curvilinear relationship between CSR and competitive conditions. Specifically, in markets where competition is either very intense (i.e. 'cutthroat' competitive conditions) or very low (i.e. in either monopolies or monopsonies) companies will disregard CSR engagement and, contrarily, will have the inclination to act in socially irresponsible ways. Yet, under normal conditions of market competition, companies are very concerned to preserve their public image and reputation as well as to safeguard customer loyalty and suppliers' trust. Thus, in such conditions firms are more likely to engage in CSR activities and endorse a socially responsible behavior.

Next, Campbell sets forth the effectiveness of the regulatory framework denoting its criticality in facilitating CSR behavior. According to his conception, well-designed - in terms of negotiation and consensus-building - as well as properly-enforced laws and regulations can mitigate social irresponsibility and effectively monitor and control business conduct. In parallel with state regulation, he further points out the need for industrial organizations to develop their own behavioral standards and self-regulation mechanisms to ensure increased CSR penetration.

The next element in Campbell's framework refers to the role of civic engagement in terms of stakeholder groups, NGOs and/or advocacy organizations which can act as 'watchdogs' and oversee corporate conduct in order to mobilize businesses to avert from alarming practices. By mobilizing media campaigns, drawing public attention, organizing demonstrations to exert pressure or appealing directly to firms such movements can minimize corporate irresponsibility and potentially contribute to incorporating CSR in corporate policies, plans and operations.

In view of the above the following hypotheses are formulated:

$H_{1}$ : National CSR penetration is dependent on the macroeconomic conditions of a country

$H_{2}$ : National CSR penetration is dependent on the level of market competition in a country

$H_{3}$ : National CSR penetration is positively associated with the regulatory effectiveness of a country. 
$H_{4}$ : National CSR penetration is positively associated with the level of self-regulation characterizing the business sector of a country.

$H_{5}$ : National CSR penetration is dependent on the level of civic engagement in a country

Campbell goes on to indicate the role of education, trade/employee associations along with fruitful stakeholder dialogue in promoting the social responsibility of forprofit organizations. He concludes his framework analysis by stressing: a) that the institutional conditions which set the 'rules of the game' for business conduct are not static but dynamically shift over time, b) that deregulation alone, in the verge of a globalized economy, does not ensure high CSR penetration but robust institutions are also necessary and c) that managerial attitudes towards CSR are critical and should be accompanied with institutional mechanisms that ensure that firms are actually behave in a socially responsible manner.

\section{Material and methods}

\subsection{Model specifications}

The proposed model specification is of the form:

$$
y=X \beta+\varepsilon
$$

with y being a $(\mathrm{n} \times 1)$ vector and $\mathrm{X}$ an $(\mathrm{nxk})$ matrix; $\beta$ and $\varepsilon$ are $(\mathrm{kx} 1)$ and $(\mathrm{n} \times 1)$ vectors respectively.

\subsection{Dependent variable: National CSR penetration}

The dependent variable y is proxied by the national CSR index (NCSRI) obtained from Skouloudis (2014) and Skouloudis et al. (2016) who extend Gjølberg's (2009) approach and utilize country data on subscription, inclusion or participation in sixteen international CSR initiatives, environmental and social standards, 'best-in-class' rankings and ethical investment stock exchange indices2. Each one of these 'components' for national CSR appraisal indicates the number of organizations endorsing the specific CSR 'variable'. Skouloudis selects the year 2012 as the reference period for data capture and a 'cut-off' value of inclusion in at least four out of the sixteen CSR 'sub-indices' (i.e. national business sectors with presence in less than four components of the NCSRI were removed from the assessment). In this respect, 86 out of the 196 countries (Appendices 1 and 2), spanning from all geographical regions of the world are ranked in terms of CSR penetration, offering an encompassing worldview of the current CSR status. Scholars (e.g. Gjølberg, 2009; Jackson and Apostolakou, 2010; have pinpointed such strong differences in CSR penetration among countries to differences in comparative institutional advantages which define to the observed aggregate variation among assessed national.

\footnotetext{
${ }^{2}$ These sixteen CSR 'variables' comprising the index are the following: ISO 14001, OHSAS 18001, SA 8000, Global Reporting Initiative, Carbon Disclosure Project, Greenhouse Gas Protocol, KPMG triennial survey on CSR reporting, Global Compact, World Business Council for Sustainable Development, Ethibel Sustainability Index, FTSE4Good Global Index, Dow Jones Sustainability World Enlarged Index, ECPI Global ESG Alpha Equity Index, MSCI World ESG Index, World's Most Ethical companies, Global 100 Most Sustainable Corporations.
} 
The ranking indicates considerable CSR penetration among only 12 countries. It is only two of those which pertain to the Asia and Pacific region (Australia and Singapore) while the rest are European countries. Switzerland, which is often considered a world hub of trading and a country where a large number of multinational groups are headquartered and/or operating, topped the ranking and is followed by three Nordic countries (Sweden, Finland and Denmark). Japan and Canada receive an approximately zero score, indicating "perfect proportionality between 'CSR companies' relative to the size of the economy" (Gjølberg, 2010: 15). In this respect, Fukukawa and Moon (2004) denote the increased exposure of Japan's business sector to global capital markets, the adoption of Western management techniques as well as governmental initiatives as critical factors of CSR proliferation in the country. Germany is assigned a negative score, with Jackson and Apostolakou (2010) to indicate that the country is often characterized a 'CSR laggard' compared to other Western European countries and that domestic firms have retained a highly ambivalent stance towards CSR initiatives while the favorable domestic economic climate relative and high level of social integration have contributed to slow public demand for CSR in the country. Emerging economies and those of developing nations received much lower scores which warrant further attention and offer fertile ground for deeper investigation (as are the cases of developed nations such as Portugal, Belgium and Spain).

\subsection{Independent variables}

$\mathrm{X}$ is the matrix including the explanatory variables of interest. Specifically, five factors are considered, referring to distinct institutional conditions characterizing a national environment, in line with Campbell's conceptual framework.

Macroeconomic conditions (MACRO) is expressed in the model specifications presented below by a) the World Economic Forum's (WEF) third pillar of the Global Competitiveness Index (GCI) referring to the macroeconomic environment (Model 1), and b) by a composite factor consisting of five figures referring to macroeconomic stability: inflation rate (\%), public debt to GDP (\%), budget surplus or deficit (as \% of GDP), current account balance (\% of GDP) and the national unemployment rate (\%) (Models 2 and 3).

Competitive conditions (COMP) are expressed by the WEF's sixth pillar of the Global Competitiveness Index (GCI) referring to domestic and foreign competition.

Regulatory effectiveness (REG) is expressed by the following five indices encapsulating the robustness and quality of the national regulatory framework: i) The Ease of Doing Business index, ii) the Corruption Perception index, iii) pillar 1A of WEF's GCI referring to public institutions along with iv) the Government Effectiveness and v) the Regulatory Quality indices of World Bank's Worldwide Governance Indicators (WGI).

Industrial self-regulation (INDUSTR) is proxied with the following WEFs GCI sub-indices pertaining to privately-established institutional arrangements: i) strength of auditing and reporting standards, ii) efficacy of corporate boards, iii) protection of minority shareholders' interests and iv) strength of investor protection. 
Civic engagement (CIV) is expressed interchangeably in our model specifications

\section{Results and discussion}

Table 1 presents the descriptive statistics of the variables considered while ordinary least squares (OLS) regression results - using three models with different variables - are reported in Table 2. In all three models there is no problem of normality.

In Model 1 only the explanatory variables are included; namely the statistical significant variables are those of macroeconomic environment (expressed by WEF's GCI pillar 3), competitive conditions, public institutions, the corruption perception index and government effectiveness. Facing increased heteroscedasticity we employed factor analysis and grouped variables in an attempt to cope with the issue. We devised three the factors, namely macroeconomic stability (consisting of the five macroeconomic figures indicated in section 3.3), regulatory effectiveness (derived from the five indices mentioned in section 3.3 which encapsulate the robustness and quality of the national regulatory framework) and industrial self- regulation (by utilizing WEFs GCI sub-indices pertaining to privately-established institutional arrangements).

In this way, Model 2 includes these three factors along with civic engagement expressed by the Freedom House's civil liberties proxy. Model 2, although better compared to Model 1, still faced problems of heteroscedasticity.

Model 3 first included all three factors and civic engagement expressed by the ISS's civic activism proxy and then was run with the same specification and the addition of the control variables (HDI and GINI). The control variable HDI was found to be statistically insignificant with a value of $\mathrm{P}=0.143$. Likewise, GINI presented Pvalues even higher and equal to 0.7 and it was omitted. Model 3 is better compared to Models 2 and 3 with no issues of heteroscedasticity.

The parameter estimates in the proposed regressions reveal that all model formulations have as explanatory variables the proxies pertaining to the macroeconomic conditions in the level of 5\% in Model 1 (macroeconomic environment) and in the 10\% significance level in Models 2 and 3 (macroeconomic stability factor). Regulatory effectiveness is statistically significant in all statistical levels; the variable industrial self-regulation is significant in all levels in Model 2 and 
in the level of 5\% in Model 3. Still the proxies of these institutional conditions are correlated with the dependent variable with very low magnitudes. Civic engagement, expressed by civil liberties in Model 2 and civic activism in the other two specifications of Model 3, are statistically significant in all levels of significance. Civil liberties and HDI are negatively correlated with NCSRI. The variable of civic activism presents very high magnitudes and a positive relationship with the dependent variable. Comparing the last two model specifications it is evident that Model 3 by employing the civic activism variable performs quite well with no indication of heteroscedasticity.

Table 1: Descriptive statistics of the variables considered

\begin{tabular}{|c|c|c|c|c|c|c|}
\hline & Mean & Median & Std. Dev. & Minimum & Maximum & Obs \\
\hline NCSRI & -18.32320 & -24.21512 & 14.43203 & -37.06495 & 20.64357 & 86 \\
\hline MACRO & -0.046512 & -5380.500 & 99999.95 & -326424.0 & 498723.0 & 86 \\
\hline REG & -0.023256 & -34013.50 & 100000.0 & -50511.00 & 723436.0 & 86 \\
\hline INDUSTR & 0.012195 & 5912.000 & 99999.98 & -267023.0 & 167964.0 & 82 \\
\hline COMP & 4.5696 & 4.567 & 0.5936 & 2.6270 & 5.8901 & 84 \\
\hline CIVACT & 0.538682 & 0.524000 & 0.053540 & 0.423000 & 0.679000 & 85 \\
\hline CIVLIB & 2.732558 & 2.000000 & 1.745073 & 1.000000 & 7.000000 & 86 \\
\hline GINI & 37.59500 & 36.50000 & 9.351476 & 23.00000 & 63.10000 & 80 \\
\hline HDI & 0.786129 & 0.806000 & 0.103517 & 0.500000 & 0.943000 & 85 \\
\hline
\end{tabular}


Table 2: OLS model results and diagnostics tests (P-Values in brackets).

\begin{tabular}{|c|c|c|c|c|c|}
\hline \multirow{2}{*}{\multicolumn{2}{|c|}{$\begin{array}{c}\text { Variables } \\
\text { Constant }\end{array}$}} & \multirow{3}{*}{$\begin{array}{c}\text { Model } 1 \\
\\
-2.8608 \\
0.0195]\end{array}$} & \multirow{3}{*}{$\begin{array}{c}\text { Model } 2 \\
-10.7278 \\
{[0.0000]}\end{array}$} & \multicolumn{2}{|c|}{ Model 3} \\
\hline & & & & \multirow{2}{*}{$\begin{array}{l}-119.17 \\
{[0.0000]}\end{array}$} & \multirow{2}{*}{$\begin{array}{l}-110.53 \\
{[0.0000]}\end{array}$} \\
\hline \multirow{2}{*}{$\begin{array}{l}\text { Macroeconomic } \\
\text { conditions }\end{array}$} & $\begin{array}{c}\text { Macroeconomic } \\
\text { environment }\end{array}$ & & & & \\
\hline & $\begin{array}{l}\text { Macroeconomic } \\
\text { stability }\end{array}$ & & $\begin{array}{c}0.000014 \\
{[0.0983]}\end{array}$ & $\begin{array}{l}0.00001 \\
{[0.0945]}\end{array}$ & $\begin{array}{c}0.0000097 \\
{[0.0979]}\end{array}$ \\
\hline \multicolumn{2}{|c|}{ Competitive conditions } & $\begin{array}{l}-11.4954 \\
{[0.0000]}\end{array}$ & & & \\
\hline \multicolumn{2}{|c|}{ Regulatory effectiveness } & & $\begin{array}{c}0.00008 \\
{[0.0000]}\end{array}$ & $\begin{array}{c}0.000034 \\
{[0.0000]}\end{array}$ & $\begin{array}{r}0.000047 \\
{[0.0032]}\end{array}$ \\
\hline \multicolumn{2}{|c|}{ Industrial self-regulation } & & $\begin{array}{c}0.000034 \\
{[0.0019]} \\
\end{array}$ & $\begin{array}{l}0.000021 \\
{[0.0161]}\end{array}$ & $\begin{array}{c}0.0000203 \\
{[0.0168]}\end{array}$ \\
\hline $\begin{array}{c}\text { Civic } \\
\text { engagement }\end{array}$ & $\begin{array}{l}\text { Civil liberties } \\
\text { Civic activism }\end{array}$ & & $\begin{array}{c}-2.7138 \\
{[0.0000]}\end{array}$ & $\begin{array}{c}187.63 \\
{[0.0000]}\end{array}$ & $\begin{array}{l}204.583 \\
{[0.0000]}\end{array}$ \\
\hline \multicolumn{2}{|c|}{ Corruption Perception Index } & $\begin{array}{c}-0.1381 \\
{[0.0131]}\end{array}$ & & & \\
\hline \multicolumn{2}{|c|}{ Public Institutions } & $\begin{array}{c}5.5402 \\
{[0.0271]}\end{array}$ & & & \\
\hline \multicolumn{2}{|c|}{ Government Effectiveness } & $\begin{array}{l}0.49524 \\
{[0.0000]}\end{array}$ & & & \\
\hline \multicolumn{2}{|c|}{ HDI } & & & & $\begin{array}{l}-22.383 \\
{[0.1429]}\end{array}$ \\
\hline \multicolumn{2}{|c|}{ R square } & 0.58 & 0.62 & 0.76 & 0.772 \\
\hline \multicolumn{2}{|c|}{ Normality test (Jarque-Bera) } & $\begin{array}{r}0.16796 \\
{[0.9194]}\end{array}$ & $\begin{array}{c}0.6513 \\
{[0.7221]}\end{array}$ & $\begin{array}{c}1.3645 \\
{[0.5055]}\end{array}$ & $\begin{array}{c}2.6459 \\
{[0.2664]}\end{array}$ \\
\hline \multicolumn{2}{|c|}{$\begin{array}{c}\text { Heteroscedasticity test } \\
\text { (Breusch-Pagan-Godfrey) }\end{array}$} & $\begin{array}{c}4,2473 \\
{[0.0018]}\end{array}$ & $\begin{array}{c}5.2363 \\
{[0.0009]}\end{array}$ & $\begin{array}{c}1.5296 \\
{[0.2021]}\end{array}$ & $\begin{array}{c}1.3232 \\
{[0.2637]}\end{array}$ \\
\hline \multicolumn{2}{|c|}{ Heteroscedasticity test (Harvey) } & $\begin{array}{l}2.2622 \\
0.0563]\end{array}$ & $\begin{array}{c}1.3549 \\
{[0.2575]}\end{array}$ & $\begin{array}{c}1.4982 \\
{[0.2112]}\end{array}$ & $\begin{array}{c}7.6859 \\
{[0.1744]}\end{array}$ \\
\hline \multicolumn{2}{|c|}{ Heteroscedasticity test (Glejser) } & $\begin{array}{c}4.1774 \\
{[0.0020]}\end{array}$ & $\begin{array}{c}4.7029 \\
{[0.0019]}\end{array}$ & $\begin{array}{c}2.4111 \\
{[0.1112]}\end{array}$ & $\begin{array}{c}1.8499 \\
{[0.1184]}\end{array}$ \\
\hline \multicolumn{2}{|c|}{ ARCH effect test } & $\begin{array}{c}2.4549 \\
{[0.1212]}\end{array}$ & $\begin{array}{c}8.3428 \\
{[0.0051]}\end{array}$ & $\begin{array}{c}0.08318 \\
{[0.7739]}\end{array}$ & $\begin{array}{c}0.000453 \\
{[0.9831]}\end{array}$ \\
\hline \multicolumn{2}{|c|}{ Heteroscedasticity test (White) } & $\begin{array}{c}2.3794 \\
{[0.0080]}\end{array}$ & $\begin{array}{c}3.0485 \\
{[0.0011]}\end{array}$ & $\begin{array}{l}1.45502 \\
{[0.1121]}\end{array}$ & $\begin{array}{c}1.42296 \\
{[0.2260]}\end{array}$ \\
\hline
\end{tabular}


A first observation on the findings is that they generally indicate partial support to Campbell's propositions as they were operationalized in this assessment. Specifically, after omitting the variables found to be insignificant, $\mathrm{H}_{1}$ is tested in all model formulations, $\mathrm{H}_{2}$ in Model $1, \mathrm{H}_{3}, \mathrm{H}_{4}$ and $\mathrm{H}_{5}$ in Models 2 and 3. In these model specifications the variance in national CSR penetration ranges from an average explanatory power of 0.58 to the relatively high level of 0.772 . Drawing from Table 2 , $\mathrm{H}_{1}$ is supported at a $2 \%$ significance level in Model 1 and at a 10\% in models 2 and 3. This shows that national CSR penetration is dependent on the macroeconomic conditions of a country. $\mathrm{H}_{2}$ is supported in all levels in Model 1 implying a very strong dependence between national CSR penetration and the level of market competition in a country. $\mathrm{H}_{3}$ is supported at all significance levels in Models 2 and 3 entailing a very strong positive association between national CSR penetration and the regulatory effectiveness of a country. $\mathrm{H}_{4}$ is supported in all significance levels in Model 2 and at a 2\% significance level in both specifications of Model 3. This implies another strong positive association between national CSR penetration and the level of self-regulation characterizing the business sector of a country. Finally, $\mathrm{H}_{5}$ is supported in all significance levels in Models 2 and 3 showing a very strong dependence between national CSR penetration and the level of civic engagement in a country.

Civic engagement appears to be the most important condition affecting CSR penetration. This finding concerning civic engagement should not come as a surprise since in a large body of the 'business in society' literature CSR is, by definition, a discretionary activity stimulated and spurred by the various expectations and demands of organizational stakeholder groups (e.g. Mitchell et al., 1997; Lozano, 2005; 2011). A stronger influence on the role of macroeconomic environment and regulatory effectiveness on national CSR penetration was expected but according to the study's model specifications they do not seem to play a critical role. Likewise, the insignificant impact of competitive conditions on national CSR requires further attention and in-depth empirical investigation.

The study has research, managerial and policy implications given the increasing importance attached to the endorsement and adoption of environmental and social responsibility. Corporate executives need to gain a better understanding of key institutional determinants of the national environment that facilitate effective CSR implementation. This is particularly important for multinational enterprises as assessments such as ours can inform the diversification of their portfolio of CSR strategies among countries of operation, increase the awareness of cross-country differences caused by institutional conditions and reexamine underlying risks of generating CSR agendas which eventually may prove to be unsuccessful. At the same time, policy-making can also benefit from such evidence in developing appropriate regional and/or country-specific CSR endorsement plans and frameworks that take into account local institutional conditions as parameters that shape CSR penetration. Indeed, policy design for CSR cannot afford to disregard of institutional parameters that influence business behavior and could act as obstacles in effective agenda-setting for sustainable development, especially in the case of developing and transition 
economies where institutions are redefined and evolving. Finally, research on CSR has so far placed comparatively less emphasis on national institutions even though nationality has been pinpointed as key parameter in the business ethics literature (e.g. O'Fallon and Butterfield, 2005). With more than a 100 countries worldwide not covered in this assessment, researchers have plenty of room to either replicate or challenge these results by devising more rigorous constructs to investigate national CSR penetration on larger samples or place their emphasis on regional trends.

\section{Concluding remarks}

These findings, exploratory in nature, are both timely and relevant, given the paucity of prior empirical evidence on the topic and emphasize the call for systematic empirical research on national institutional mechanisms and arrangements that influence CSR engagement. One possible explanation of the statistical results may be that the study's sample contains data only for one year; an assessment that captures relevant data over a time series and employs panel data analysis could challenge or bolster these results. Further research could not only amend the aforementioned limitations but also include and test additional institutional conditions set forth in Campbell's framework (referring to the role of education, trade/employee associations and stakeholder dialogue in promoting CSR) by devising appropriate variables. Additionally, the variables employed in the study in order to assess the institutional conditions may not fully reflect Campbell's conception and researchers may employ different proxies with probably better fit.

Still, this paper demonstrates that empirical research on the institutional parameters influencing CSR is a field that needs further investigation with the use of both refined statistical techniques as well as in-depth qualitative approaches that focus on country groups (e.g. high-low income countries) in order to explain regional discrepancies in CSR penetration. Likewise, assessing through large cross country samples the moderating effects of informal institutions (e.g. cultural traits and religious beliefs) on CSR could provide a better understanding of the tensions between the nexus of national institutions and socially responsible business behavior.

\section{References}

Aguilera, R.V., Rupp, D.E., Williams, C.A., \& Ganapathi, J., 2007. Putting the S back in corporate social responsibility: A multilevel theory of social change in organizations. Academy of Management Review 32, 836-863.

Bansal, P., Roth, K., 2000. Why companies go green: A model of ecological responsiveness. Academy of Management Journal 43, 717-736.

Barley, S.R., 2007. Corporations, democracy, and the public good. Journal of Management Inquiry 16, 201-215.

Baskin, J., 2006. Corporate responsibility in emerging markets. Journal of Corporate Citizenship 24, 29-47. 
Brammer, S., Jackson, G., Matten, D., 2012. Corporate social responsibility and institutional theory: New perspectives on private governance. Socio-Economic Review 10, 3-28.

Campbell, J.L., 2007. Why would corporations behave in socially responsible ways? An institutional theory of corporate social responsibility. Academy of Management Review 32, 946-967.

Chen, S., Bouvain, P., 2009. Is corporate responsibility converging? A comparison of corporate responsibility reporting in the USA, UK, Australia, and Germany. Journal of Business Ethics 87, 299-317.

Fukukawa K., Moon, J., 2004. A Japanese model of corporate social responsibility? A study of website reporting. Journal of Corporate Citizenship 16, 4559.

Galaskiewicz, J., 1997. An urban grants economy revisited: corporate charitable contributions in the twin cities, 1979-1981, 1987-1989. Administrative Science Quarterly 42, 445-471.

Gedajlovic, E.R., Shapiro, D.M., 1998. Management and ownership effects: Evidence from five countries. Strategic Management Journal 19, 533-553.

Gjølberg, M., 2009. Measuring the immeasurable? Constructing an index of CSR practices and performance in 20 countries. Scandinavian Journal of Management 25, $10-22$.

Globerman, S., Shapiro, D., 2002. Global foreign direct investment flows: The role of governance infrastructure. World Development 31, 1899-1919.

Guthrie, D., McQuarrie, M., 2004. Corporate investment, social innovation, and community change: The local political economy of low-income housing development. New York University, New York.

Harms, P., Ursprung, H.W., 2002. Do civil and political repression really boost foreign direct investments? Economic Inquiry 40, 651-663.

Hoffman, A.J., 1999. Institutional evolution and change: Environmentalism and the US chemical industry. Academy of Management Journal 42, 351-371.

Jamali, D., Sidani, Y., El-Asmar, K., 2009. A three country comparative analysis of managerial CSR perspectives: Insights from Lebanon, Syria and Jordan. Journal of Business Ethics 85, 173-192.

Jamali, D., Neville, B., 2011. Convergence versus divergence of CSR in developing countries: An embedded multi-layered institutional lens. Journal of Business Ethics 102, 599-621.

Khanna, T., Kogan, J., Palepu, K., 2006. Globalization and similarities in corporate governance: A cross-country analysis. Review of Economics and Statistics 88, 69-90.

Lozano, J.M., 2005. Towards the relational corporation: From managing stakeholder relationships to building stakeholder relationships (waiting for Copernicus). Corporate Governance: The international journal of business in society $5,60-77$.

Lozano, R., 2011. Addressing stakeholders and better contributing to sustainability through game theory. Journal of Corporate Citizenship 2011(43), 45-62. 
Lozano, R., 2012. Towards better embedding sustainability into companies' systems: an analysis of voluntary corporate initiatives. Journal of Cleaner Production $25,14-26$.

Margolis, J.D., Elfenbein, H.A., Walsh, J.P., 2007. Does it pay to be good? A meta-analysis and redirection of research on the relationship between corporate social and financial performance. Ann Arbor 1001, 48109-1234.

Marquis, C., Glynn, M.A., Davis, G.F., 2007. Community isomorphism and corporate social action. Academy of Management Review 32, 925-945.

O'Fallon, M.J., Butterfield, K.D., 2005. A review of the empirical ethical decisionmaking literature: 1996-2003. Journal of Business Ethics 59, 375-413.

Porter, M., Kramer, M., 2006. Strategy and society: The link between competitive advantage and corporate social responsibility. Harvard Business Review 84, 77-92.

Sharma, S., 2000. Managerial interpretations and organizational context as predictors of corporate choice of environmental strategy. Academy of Management Journal 43, 681-697.

Skouloudis, A., 2014. Revisiting the development of a national corporate social responsibility index. MPRA Paper 64864, University Library of Munich, Munich.

Skouloudis, A., Isaac, D., Evaggelinos, K., 2016. Revisiting the national corporate social responsibility index. International Journal of Sustainable Development \& World Ecology 23, 61-70.

Thelen, K., 1999. Historical Institutionalism in Comparative Politics. American Review of Political Science 2, 369-404.

Vilanova, M., Lozano, J.M., Arenas, D., 2009. Exploring the nature of the relationship between CSR and competitiveness. Journal of Business Ethics 87, 57-69.

Welford, R., 2003. Corporate social responsibility in Europe and Asia: Critical elements and best practice. Journal of Corporate Citizenship 13, 31-47.

Welford, R., 2005. Corporate social responsibility in Europe, North America and Asia: 2004 survey results. Journal of Corporate Citizenship 17, 33-52.

Wood, D.J., 2010. Measuring corporate social performance: A review. International Journal of Management Reviews 12, 50-84.

Williams, C.A., Aguilera, R.V., 2008. Corporate social responsibility in a comparative perspective. In A. Crane, A. McWilliams, D. Matten, J. Moon, D. Siegel (eds.), Oxford handbook of corporate social responsibility, 452-472. Oxford University Press, Oxford.

Witt, M.A., Redding, G., 2012. The spirits of corporate social responsibility: Senior executive perceptions of the role of the firm in society in Germany, Hong Kong, Japan, South Korea and the USA. Socio-Economic Review 10, 109-134. 
Appendix 1: Country scores according to the national corporate responsibility index of Skouloudis (2014) and Skouloudis et al. (2016). Note: $(*)$ Advanced economies, $(\wedge)$ Emerging economies, $(* *)$ Developing economies

\begin{tabular}{|c|c|c|}
\hline & Country & NCSRI \\
\hline 1 & Switzerland * & 20,64 \\
\hline 2 & Sweden $*$ & 19,50 \\
\hline 3 & Finland $*$ & 18,99 \\
\hline 4 & Denmark * & 12,59 \\
\hline 5 & United Kingdom * & 9,64 \\
\hline 6 & Netherlands $*$ & 9,27 \\
\hline 7 & Norway * & 8,04 \\
\hline 8 & Australia * & 6,17 \\
\hline 9 & Spain * & 4,21 \\
\hline 10 & France * & 2,58 \\
\hline 11 & Portugal * & 2,30 \\
\hline 12 & Singapore $*$ & 0,77 \\
\hline 13 & Japan * & $-0,25$ \\
\hline 14 & Canada & $-0,76$ \\
\hline 15 & Belgium * & $-1,22$ \\
\hline 16 & Italy * & $-1,56$ \\
\hline 17 & Germany & $-3,93$ \\
\hline 18 & Hong Kong * & $-5,40$ \\
\hline 19 & Ireland * & $-5,70$ \\
\hline 20 & USA * & $-11,02$ \\
\hline 21 & Luxembourg * & $-11,12$ \\
\hline 22 & Brazil $^{\wedge}$ & $-11,74$ \\
\hline 23 & Colombia $^{\wedge}$ & $-11,99$ \\
\hline 24 & South Korea * & $-12,13$ \\
\hline 25 & Austria * & $-12,21$ \\
\hline 26 & South Africa $\wedge$ & $-12,58$ \\
\hline 27 & Israel * & $-13,57$ \\
\hline 28 & Chile $\wedge$ & $-15,13$ \\
\hline 29 & New Zealand * & $-15,19$ \\
\hline
\end{tabular}

\begin{tabular}{|c|c|c|}
\hline & Country & NCSRI \\
\hline 30 & Greece * & $-15,36$ \\
\hline 31 & Thailand $^{\wedge}$ & $-17,79$ \\
\hline 32 & Romania $^{\wedge}$ & $-17,98$ \\
\hline 33 & Malaysia $\wedge$ & $-18,99$ \\
\hline 34 & Hungary $\wedge$ & $-19,50$ \\
\hline 35 & Bulgaria $\wedge$ & $-19,68$ \\
\hline 36 & India $\wedge$ & $-20,64$ \\
\hline 37 & Lithuania * & $-20,87$ \\
\hline 38 & Slovakia $*$ & $-21,73$ \\
\hline 39 & Taiwan * & $-22,02$ \\
\hline 40 & Croatia $\wedge$ & $-23,07$ \\
\hline 41 & Panama $* *$ & $-23,41$ \\
\hline 42 & Slovenia $*$ & $-23,83$ \\
\hline 43 & United Arab Emirates * & $-24,17$ \\
\hline 44 & Serbia $* *$ & $-24,26$ \\
\hline 45 & Sri Lanka $* *$ & $-24,39$ \\
\hline 46 & Latvia * & $-24,81$ \\
\hline 47 & Indonesia $^{\wedge}$ & $-25,03$ \\
\hline 48 & Estonia * & $-25,12$ \\
\hline 49 & Jordan $* *$ & $-25,19$ \\
\hline 50 & Bahrain ** & $-25,41$ \\
\hline 51 & Viet $\operatorname{Nam} * *$ & $-25,55$ \\
\hline 52 & Mauritius $* *$ & $-26,04$ \\
\hline 53 & Czech Republic * & $-26,25$ \\
\hline 54 & Iceland * & $-26,36$ \\
\hline 55 & Poland $^{\wedge}$ & $-26,36$ \\
\hline 56 & China $\wedge$ & $-26,65$ \\
\hline 57 & Peru $\wedge$ & $-26,66$ \\
\hline 58 & Uruguay $* *$ & $-26,98$ \\
\hline
\end{tabular}

\begin{tabular}{|c|c|c|}
\hline & Country & NCSRI \\
\hline 59 & $\operatorname{Mexico}^{\wedge}$ & $-27,36$ \\
\hline 60 & Kazakhstan $^{\wedge}$ & $-27,53$ \\
\hline 61 & Turkey $^{\wedge}$ & $-27,78$ \\
\hline 62 & Costa Rica ** & $-27,84$ \\
\hline 63 & Ecuador $* *$ & $-28,06$ \\
\hline 64 & Pakistan $\wedge$ & $-28,10$ \\
\hline 65 & Argentina $^{\wedge}$ & $-28,37$ \\
\hline 66 & Bolivia $* *$ & $-28,37$ \\
\hline 67 & Philippines $^{\wedge}$ & $-29,56$ \\
\hline 68 & Qatar ** & $-29,65$ \\
\hline 69 & Belarus $^{\wedge}$ & $-30,18$ \\
\hline 70 & Tunisia $* *$ & $-30,26$ \\
\hline 71 & Honduras $* *$ & $-30,43$ \\
\hline 72 & Kuwait $* *$ & $-30,65$ \\
\hline 73 & Kenya $* *$ & $-30,79$ \\
\hline 74 & Egypt $* *$ & $-31,45$ \\
\hline 75 & Ukraine $^{\wedge}$ & $-31,66$ \\
\hline 76 & Georgia $^{\wedge}$ & $-32,26$ \\
\hline 77 & Russian Federation ${ }^{\wedge}$ & $-32,38$ \\
\hline 78 & Oman $* *$ & $-32,50$ \\
\hline 79 & Nigeria $* *$ & $-33,13$ \\
\hline 80 & Guatemala ** & $-33,51$ \\
\hline 81 & Syrian Arab Republic** & $-33,70$ \\
\hline 82 & Morocco ** & $-33,94$ \\
\hline 83 & $\operatorname{Iran} * *$ & $-34,00$ \\
\hline 84 & Bangladesh $^{\wedge}$ & $-34,93$ \\
\hline 85 & Venezuela $^{\wedge}$ & $-35,44$ \\
\hline 86 & Saudi Arabia ** & $-37,06$ \\
\hline
\end{tabular}




\begin{tabular}{|c|c|c|c|}
\hline & & Europe & NCSRI \\
\hline 1 & 1 & Switzerland * & 20,64 \\
\hline 2 & 2 & Sweden * & 19,50 \\
\hline 3 & 3 & Finland * & 18,99 \\
\hline 4 & 4 & Denmark * & 12,59 \\
\hline 5 & 5 & United Kingdom * & 9,64 \\
\hline 6 & 6 & Netherlands * & 9,27 \\
\hline 7 & 7 & Norway * & 8,04 \\
\hline 8 & 9 & Spain * & 4,21 \\
\hline 9 & 10 & France * & 2,58 \\
\hline 10 & 11 & Portugal * & 2,30 \\
\hline 11 & 15 & Belgium * & $-1,22$ \\
\hline 12 & 16 & Italy * & $-1,56$ \\
\hline 13 & 17 & Germany & $-3,93$ \\
\hline 14 & 19 & Ireland * & $-5,70$ \\
\hline 15 & 21 & Luxembourg * & $-11,12$ \\
\hline 16 & 25 & Austria * & $-12,21$ \\
\hline 17 & 30 & Greece * & $-15,36$ \\
\hline 18 & 32 & Romania $^{\wedge}$ & $-17,98$ \\
\hline 19 & 34 & Hungary $\wedge$ & $-19,50$ \\
\hline 20 & 35 & Bulgaria $\wedge$ & $-19,68$ \\
\hline 21 & 37 & Lithuania * & $-20,87$ \\
\hline 22 & 38 & Slovakia * & $-21,73$ \\
\hline 23 & 40 & Croatia $\wedge$ & $-23,07$ \\
\hline 24 & 42 & Slovenia * & $-23,83$ \\
\hline 25 & 44 & Serbia $* *$ & $-24,26$ \\
\hline 26 & 46 & Latvia * & $-24,81$ \\
\hline 27 & 48 & Estonia * & $-25,12$ \\
\hline 28 & 53 & Czech Republic * & $-26,25$ \\
\hline 29 & 54 & Iceland $*$ & $-26,36$ \\
\hline 30 & 55 & Poland $^{\wedge}$ & $-26,36$ \\
\hline
\end{tabular}

\begin{tabular}{|c|c|c|c|}
\hline & & Asia - Pacific & NCSRI \\
\hline 1 & 8 & Australia * & 6,17 \\
\hline 2 & 12 & Singapore * & 0,77 \\
\hline 3 & 13 & Japan * & $-0,25$ \\
\hline 4 & 18 & Hong Kong * & $-5,40$ \\
\hline 5 & 24 & South Korea * & $-12,13$ \\
\hline 6 & 29 & New Zealand * & $-15,19$ \\
\hline 7 & 31 & Thailand $^{\wedge}$ & $-17,79$ \\
\hline 8 & 33 & Malaysia $\wedge$ & $-18,99$ \\
\hline 9 & 36 & India $\wedge$ & $-20,64$ \\
\hline 10 & 39 & Taiwan * & $-22,02$ \\
\hline 11 & 45 & Sri Lanka ** & $-24,39$ \\
\hline 12 & 47 & Indonesia $^{\wedge}$ & $-25,03$ \\
\hline 13 & 51 & Viet Nam $* *$ & $-25,55$ \\
\hline 14 & 56 & China $\wedge$ & $-26,65$ \\
\hline 15 & 64 & Pakistan $\wedge$ & $-28,10$ \\
\hline 16 & 67 & Philippines $\wedge$ & $-29,56$ \\
\hline 17 & 84 & Bangladesh $\wedge^{\wedge}$ & $-34,93$ \\
\hline
\end{tabular}

\begin{tabular}{|c|c|lc|}
\hline & & Greater Middle East & NCSRI \\
\hline 1 & 27 & Israel * & $-13,57$ \\
2 & 43 & United Arab Emirates * & $-24,17$ \\
3 & 49 & Jordan ** & $-25,19$ \\
4 & 50 & Bahrain ** & $-25,41$ \\
5 & 61 & Turkey & $-27,78$ \\
6 & 68 & Qatar ** & $-29,65$ \\
7 & 70 & Tunisia ** & $-30,26$ \\
8 & 72 & Kuwait ** & $-30,65$ \\
9 & 74 & Egypt ** & $-31,45$ \\
10 & 78 & Oman ** & $-32,50$ \\
11 & 81 & Syrian Arab Republic** & $-33,70$ \\
12 & 82 & Morocco ** & $-33,94$ \\
13 & 83 & Iran ** & $-34,00$ \\
14 & 86 & Saudi Arabia ** & $-37,06$ \\
\hline
\end{tabular}

\begin{tabular}{|c|c|c|c|}
\hline & & Central \& South America & NCSRI \\
\hline 1 & 22 & Brazil $\wedge^{\wedge}$ & $-11,74$ \\
\hline 2 & 23 & Colombia $^{\wedge}$ & $-11,99$ \\
\hline 3 & 28 & Chile ${ }^{\wedge}$ & $-15,13$ \\
\hline 4 & 41 & Panama ** & $-23,41$ \\
\hline 5 & 57 & Peru $\wedge$ & $-26,66$ \\
\hline 6 & 58 & Uruguay $* *$ & $-26,98$ \\
\hline 7 & 62 & Costa Rica ** & $-27,84$ \\
\hline 8 & 63 & Ecuador ** & $-28,06$ \\
\hline 9 & 65 & Argentina $^{\wedge}$ & $-28,37$ \\
\hline 10 & 66 & Bolivia $* *$ & $-28,37$ \\
\hline 11 & 71 & Honduras $* *$ & $-30,43$ \\
\hline 12 & 80 & Guatemala ** & $-33,51$ \\
\hline 13 & 85 & Venezuela $^{\wedge}$ & $-35,44$ \\
\hline
\end{tabular}

\begin{tabular}{|c|c|c|c|}
\hline & & North America & NCSRI \\
\hline 1 & 14 & Canada & $-0,76$ \\
\hline 2 & 20 & USA * & $-11,02$ \\
\hline 3 & 59 & $\operatorname{Mexico}^{\wedge}$ & $-27,36$ \\
\hline & \multicolumn{2}{|c|}{ Commonwealth of Ind. States } & NCSRI \\
\hline 1 & 60 & Kazakhstan $^{\wedge}$ & $-27,53$ \\
\hline 2 & 69 & Belarus ^ & $-30,18$ \\
\hline 3 & 75 & Ukraine $^{\wedge}$ & $-31,66$ \\
\hline 4 & 76 & Georgia $^{\wedge}$ & $-32,26$ \\
\hline 5 & 77 & Russian Federation $^{\wedge}$ & $-32,38$ \\
\hline
\end{tabular}

\begin{tabular}{|l|l|lr|}
\hline & & Sub-Saharan Africa & NCSRI \\
\hline 1 & 26 & South Africa & \\
2 & 52 & Mauritius ** & $-12,58$ \\
3 & 73 & Kenya $* *$ & $-26,04$ \\
4 & 79 & Nigeria $* *$ & $-30,79$ \\
\end{tabular}

Appendix 2: Country groupings and national CSR scores; first two columns indicate the regional and overall rankings respectively.

Note: Ukraine and Georgia are not members of the Commonwealth of Independent States but we included them in this group due to geographical proximity and similarities in economic structure. 